\title{
Enhancement of Human Natural Killer Cells by Interferon Requires RNA and Protein Synthesis
}

\author{
Gail Abendroth Bishop ${ }^{1}$ and Stanley A. Schwartz \\ Departments of Pediatrics and Epidemiology. The University of Michigan \\ Ann Arbor, Michigan 48109
}

\begin{abstract}
An enriched population of human natural killer (NK) cells was obtained by density gradient centrifugation. The cytotoxic activity of these cells was enhanced by pretreatment with human leukocyte interferon (IF), and the metabolic requirements of this enhancement were examined. Augmentation of NK activity was initiated in a rapid, temperature-independent manner, requiring only a 10- to 15 -min exposure to IF, and occurred at either 4 or $37^{\circ} \mathrm{C}$. Increased activity of the IF-treated NK effector cells was consistently observed after only 30 min of contact with target cells. Augmentation was inhibited by prior treatment of NK effector cells with actinomycin D (AD), but treatmenf with $\mathrm{AD}$ after $1 \mathrm{hr}$ of IF treatment did not inhibit the IF-mediated increase in cytotoxicity, suggesting that the RNA species required for enhancement are synthesized within 1 $\mathrm{hr}$ of cell-IF interaction. Protein synthesis was required for at least $1 \mathrm{hr}$ following cell-IF interaction, as shown by the ability of emetine and puromycin treatments to abrogate increased NK cell activity. Binding of IF to cells was independent of protein synthesis. IF-induced enhancement was unaffected by incubation of effector cells with mitomycin $\mathrm{C}$ either before or after IF treatment, indicating that IF acts primarily upon a population of preexisting cells of lower NK activity.
\end{abstract}

\section{INTRODUCTION}

The antiviral properties of the glycoproteins called the interferons have been the subject of numerous investigations since their discovery over two decades ago (1). Only in recent years has come the recognition that interferon (IF) ${ }^{2}$ can also exert a variety of significant effects upon immunological functions. One of these effects is the enhancement by IF of natural killer (NK) cell activity, a lymphocyte-mediated cytotoxic reaction against virus-infected or malignantly transformed target cells which does not require previous exposure of the effector cells to the targets $(2-5)$.

The subset of lymphocytes mediating NK activity in man has not been completely defined, although a number of methods have been used to further purify 'NK effector cells. These include enrichment of cells with Fc receptors (6), adsorption and elution from target cells, and density and velocity fractionation (7). Recently, the latter technique has been utilized by Timonen and Saksela ( 8 ), who devised a density gradient of a colloidal silica medium (Percoll) which permits considerable enrichment of NK effector cells. Using a modification of this procedurc, we have obtained a highly enriched population of NK effector cells from

${ }^{t}$ Predoctoral Fellow in the Program in Cellular and Molecular Biology. To whom all correspondence should be addressed: The University of Michigan, School of Public Health 1, Department of Epidemiology, Room 2022, Ann Arbor, Mich. 48109.

${ }^{2}$ Abbreviations used: AD, actinomycin D: CM, complete medium: EM, emetine $\mathrm{HCl}: \mathrm{IF}$, human leukocyte interferon: IL-2, interleukin-2; MC, mitomycin C: NK. natural killer; PBMC, peripheral blood mononuclear cells; PHA, phytohemagglutinin-P; PM, puromycin. 
human peripheral blood. We were thus able to examine the effects of IF upon the cells more directly responsible for mediating the NK reaction.

Interest in the mechanisms of NK cell activity has been increasing due to its potential role in immunologic defense against tumors $(9-14)$, and self-regulation of lymphoid cell functions (15-17). The antitumor properties of IF are also currently under investigation, both in the laboratory and in clinical trials (18). Since the ability of IF to act against malignant cells in man may be partially due to its enhancement of the NK reaction, it is important to gain greater knowledge of the events involved in this enhancement. The cellular and biochemical mechanisms associated with IF-mediated augmentation of the NK reaction are still largely unknown.

Although natural cytotoxicity has been observed in both murine and human systems, significant interspecies differences exist in its expression. An age-related decline in murine NK activity is not paralleled in man (19). While the greatest tissue-associated murine NK activity is observed in spleen, in man peripheral blood lymphocytes manifest the highest NK activity, and human NK cells are significantly more radiosensitive than their murine counterparts (7). We thus cxamined IF-enhanced NK activity in the human to compare the biochemical requirements of this enhancement to those in the mouse $(20,21)$. The present study extends previous investigations in which total human peripheral blood mononuclear cells (PBMC) were used (22) by utilizing a highly enriched population of NK effector lymphocytes. Since total PBMC contain cell populations which can themselves modify NK activity, it is important to determine the effects of IF on purified NK effector cell populations.

\section{MATERIALS AND METHODS}

Lymphocyte separation. PBMC were separated from heparinized venous blood of healthy adult donors by Ficoll-Hypaque density gradient centrifugation (23). Cells were washed three times with $0.85 \% \mathrm{NaCl}$ and resuspended in RPMI 1640 culture medium containing $5 \%$ fetal calf serum, fresh glutamine $(300 \mu \mathrm{g} / \mathrm{ml})$, and antibiotics (hereafter referred to as complete medium, CM). Cells were depleted of monocytes by incubation on a column of Sephadex G-10 (Pharmacia Chemicals, Piscataway, N.J.) according to the method of Ly and Mishell (24). Cells eluted from this column contained $<1 \%$ esterase-positive monocytes.

Percoll enrichment of NK effector cells. Discontinuous density gradients of Percoll (Pharmacia) were prepared as described by Timonen and Saksela (8) with slight modifications. Percoll was diluted to various concentrations in RPMI 1640 medium, and $2-\mathrm{ml}$ volumes of each fraction were layered into a $15 \times 105-\mathrm{mm}$ glass test tube. These gradients consisted of six fractions, starting with $50 \%$ Percoll (fraction 5) and decreasing by $2.5 \%$ increments to $37.5 \%$ (fraction 0). Monocytedepleted lymphocytes were layered on top of this gradient and centrifuged at $300 \mathrm{~g}$ for $45 \mathrm{~min}$ at $22^{\circ} \mathrm{C}$. Fractions were collected with a Pasteur pipet and washed twice in CM.

Results of 18 experiments consistently demonstrated the highest NK activity in fractions 0 and 1 (Fig. 1). We then employed a simpler, three-layer gradient to 


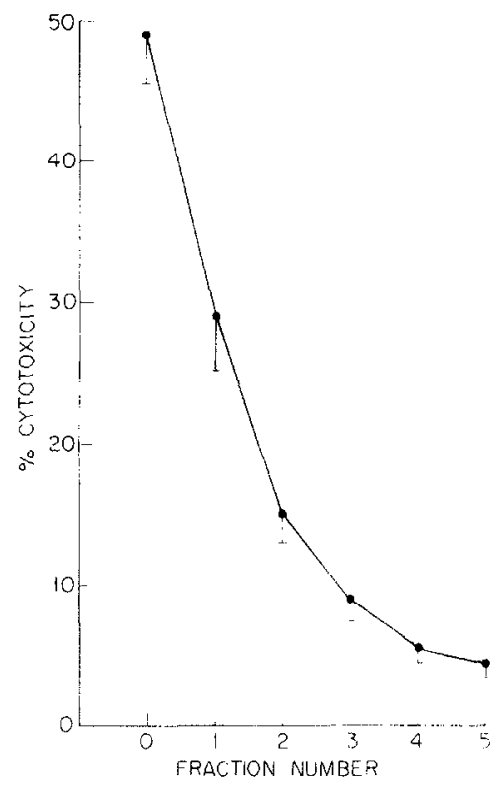

FIG. 1. Density gradient separation of NK cells. Monocyte-depleted lymphocytes were layered onto a gradient of six Percoll fractions. Fractions $0-5$ represent 37.5, 40.0, 42.5, 47.5, and 50\% Percoll, respectively. Results represent mean $\pm S E$ of experiments using 18 different donors.

enrich for NK effectors in subsequent experiments. This gradient consisted of 4 -ml layers of 40,45 , and $50 \%$ Percoll in a $15 \times 105$-mm glass tube. Centrifugation was performed as above, and the cells from the $40 \%$ interface were used as NK effector cells in all subsequent experiments. Cells found at this $40 \%$ interface were shown in eight experiments to possess $\mathrm{NK}$ activity not significantly different from cells found at the fraction 0 interface in the six-layer gradient.

NK target cells. The human leukemic cell line, K562, recently shown to be of probable erythroid origin (25), was used as targets for NK cells. K562 cells passaged $48 \mathrm{hr}$ prior to the day of use were labeled by the addition of $200 \mu \mathrm{Ci}$ of $\mathrm{Na}_{2}$ ${ }^{51} \mathrm{CrO}_{4}\left(200-500 \mathrm{Ci} / \mathrm{g}\right.$, New England Nuclear, Boston, Mass.) to $5 \times 10^{6} \mathrm{~K} 562$ cells in $0.8 \mathrm{ml} \mathrm{CM}$. The cells were incubated for $1 \mathrm{hr}$ at $37^{\circ} \mathrm{C}$ in a humid $5 \% \mathrm{CO}_{2}$, 95\% air almosphere, with frequent shaking. Cells were then washed three times with $\mathrm{CM}$ and resuspended to a concentration of $10^{5} / \mathrm{ml}$.

NK cytotoxicity assay. NK activity was measured by a $4 \mathrm{hr}$ direct ${ }^{51} \mathrm{Cr}$-release assay, except where noted. The effector-to-target ratio was 20:1 in all experiments unless stated otherwise, as this ratio was selected from a number of previously tested ratios as providing optimal results. Thus, $2 \times 10^{5}$ viable effector cells were added to $10^{4}$ labeled viable target cells in triplicate cultures of $0.2 \mathrm{ml}$ each in V-bottom microtitration plates (CoStar, Cambridge, Mass.). Plates were centrifuged at $40 \mathrm{~g}$ for $5 \mathrm{~min}$, then incubated $4 \mathrm{hr}$ at $37^{\circ} \mathrm{C}$ in a humid $5 \% \mathrm{CO}_{2}, 95 \%$ air atmosphere. At the completion of incubation, plates were centrifuged at $700 \mathrm{~g}$ for $5 \mathrm{~min}$, and $0.1 \mathrm{ml}$ of culture supernatant was harvested from each well and 
counted in a Packard Model 5320 gamma spectrometer. Percentage cytotoxicity was calculated as

$$
\text { pcrcentagc cytotoxicity }=\frac{\text { experimental release }- \text { spontaneous release }}{\text { total counts }- \text { spontaneous release }} \times 100 \text {, }
$$

where spontaneous release represents counts released from wells containing $10^{4}$ target cells alone, and total counts represents counts contained in an aliquot of $10^{4}$ target cells.

IF augmentation of NK effector cells. NK effector cells, isolated as described above, were suspended at a cell density of $5 \times 10^{6}$ cells $/ \mathrm{ml}$ in $\mathrm{CM}$ containing 500 $\mathrm{U} / \mathrm{ml}$ of partially purified human leukocyte IF (sp act $6.3 \times 10^{4}$ units $/ \mathrm{mg}$ protein, a kind gift from Parke-Davis and Co., Detroit, Mich.). Cells were incubated with IF for $1 \mathrm{hr}$ at $37^{\circ} \mathrm{C}$ in a humid $5 \% \mathrm{CO}_{2}, 95 \%$ air atmosphere, except where noted, and were washed prior to use.

Drug treatments. Cells were incubated at a density of $5 \times 10^{6}$ cells $/ \mathrm{ml}$ in CM containing the stated concentrations of drugs, at $37^{\circ} \mathrm{C}$. All incubations with drugs lasted 45 min except incubations with puromycin (PM), which were maintained for $1 \mathrm{hr}$. Cells were washed following treatment unless stated otherwise. The drugs used, mitomycin $\mathrm{C}(\mathrm{MC})$, actinomycin $\mathrm{D}(\mathrm{AD})$, emetine $\mathrm{HCl}(\mathrm{EM})$, and puromycin (PM), were all purchased from Sigma Chemical Company, St. Louis, Missouri. None of the drug treatments decreased cell viability as determined by trypan bluc cxclusion. All drug solutions were prepared fresh on the day of use.

Assays of DNA, RNA, and protein synthesis. Following drug and/or IF treatments, aliquots of each experimental effector cell suspension were used to simultaneously assay NK activity and DNA, RNA, or protein synthesis. The latter were quantitated via the incorporation of $\left[{ }^{3} \mathrm{H}\right]$ thymidine, $\left[{ }^{3} \mathrm{H}\right]$ uridine, and $\left[{ }^{3} \mathrm{H}\right]$ leucine, respectively. All radiochemicals were purchased from New England Nuclear, Boston, Massachusetts. In these assays, $5 \mu \mathrm{g}$ of phytohemagglutinin-P (PHA, Difco, Labs, Detroit, Mich.) were added to each culture well. Control cultures without PHA were included in each experiment, and although the absolute incorporation of radiolabel was consistently greater in the mitogen-stimulated cultures, the qualitative pattern of the drug effects on stimulated and unstimulated cultures was comparable.

To assay DNA synthesis, $2 \times 10^{5}$ cells were incubated in a volume of $0.2 \mathrm{ml}$ of $\mathrm{CM}$ in triplicate in round-bottom microtitration plates (CoStar). Cultures were incubated at $37^{\circ} \mathrm{C}$ for $72 \mathrm{hr} ; 18 \mathrm{hr}$ prior to harvesting, $2 \mu \mathrm{Ci}$ of $\left[{ }^{3} \mathrm{H}\right]$ thymidine $(6.7$ $\mathrm{Ci} / \mathrm{mmol}$ ) were added to each well. Cultures were harvested onto glass fiber filters using an automated cell harvester. Filters were dried and placed in scintillation vials containing $1 \mathrm{ml}$ of Hydrofluor (National Diagnostics, Somerville, N.J.). Vials were counted in a Beckman Model I S 7000 scintillation counter.

To assay RNA synthesis, cells were plated as described above and cultured for $18 \mathrm{hr}$ in the presence of $\left[{ }^{3} \mathrm{H}\right]$ uridine $(37.6 \mathrm{Ci} / \mathrm{mmol})$ at $1 \mu \mathrm{Ci} /$ well. The cells were harvested on glass fiber filters as above and acid-precipitable material was precipitated with $6 \%$ sulfosalicylic acid. Filters were dried and counted as above.

To assay protein synthesis, cells in CM were centrifuged following removal of 
aliquots for NK assay, and resuspended in leucine-free minimal essential medium containing 5\% fetal calf serum. Cells were plated as above and cultured for $4 \mathrm{hr}$ in the presence of $2 \mu \mathrm{Ci}$ of $\left[{ }^{3} \mathrm{H}\right]$ leucine $(55.9 \mathrm{Ci} / \mathrm{mmol})$ per well. Cells were harvested and acid-precipitable material counted as previously described.

Statistical analysis of data. Statistical significance of the effects of separate and combined drug and IF treatments upon NK cytotoxicity was determined by analysis of variance, using a computer program provided by the Biostatistics Computing Center of The University of Michigan, Ann Arbor, Michigan.

\section{RESULTS}

Temperature and time dependence of IF-induced NK augmentation. To determine the effects of temperature of incubation and duration of IF treatment upon IF-induced NK augmentation, Percoll-enriched NK effector cells were treated with $500 \mathrm{U} / \mathrm{ml}$ of IF at 4 or $37^{\circ} \mathrm{C}$ for varying periods of time. The results, presented in Fig. 2, show that IF-induced augmentation occurs rapidly at either 4 or $37^{\circ} \mathrm{C}$. although a slightly greater enhancing effect is seen when cells are incubated with IF at $37^{\circ} \mathrm{C}$. Statistically significant $(P=0.05)$ enhancement is observed after only 15 min of IF treatment. IF thus seems to interact quickly with NK effector cells, even at a nonphysiologic temperature.

To determine the kinetics of IF enhancement of NK activity, effector cells were incubated with $500 \mathrm{U} / \mathrm{ml}$ of IF for $1 \mathrm{hr}$ at $37^{\circ} \mathrm{C}$. Cells were then washed, added to labeled target cells, and percentage cytotoxicity was determined at $0.5,1,2.4$, and $8 \mathrm{hr}$. Results, shown in Fig. 3, demonstrate that the percentage cytotoxicity of IF-treated cultures is consistently greater than untreated cultures, and the difference is apparent after only $15 \mathrm{~min}$ of IF interaction with target cells. However. statistically significant differences were reached only after $2 \mathrm{hr}$.

Effects of MC on IF-induced NK augmentation. DNA synthesis of Percollenriched NK effector cells was inhibited by treatment with $0.5,5$, or $50 \mu \mathrm{g} / \mathrm{ml}$ of $\mathrm{MC}$ for $45 \mathrm{~min}$ at $37^{\circ} \mathrm{C}$ either before or after IF treatment. Cells were then tested

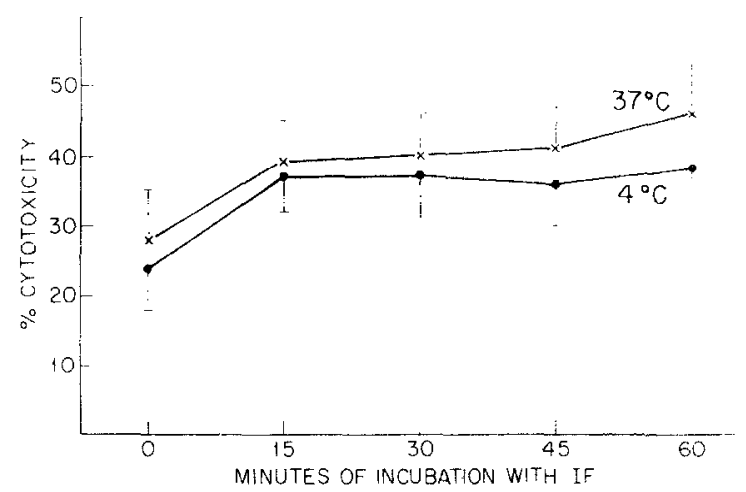

FIG. 2. Effect of temperature on IF augmentation of NK activity. NK cells were treated with 500 $\mathrm{U} / \mathrm{ml}$ of IF for $0,15,30,45$, or $60 \mathrm{~min}$ at 4 or $37^{\circ} \mathrm{C}$. Results represent mean $\pm \mathrm{SE}$ of experiments using three different donors. 


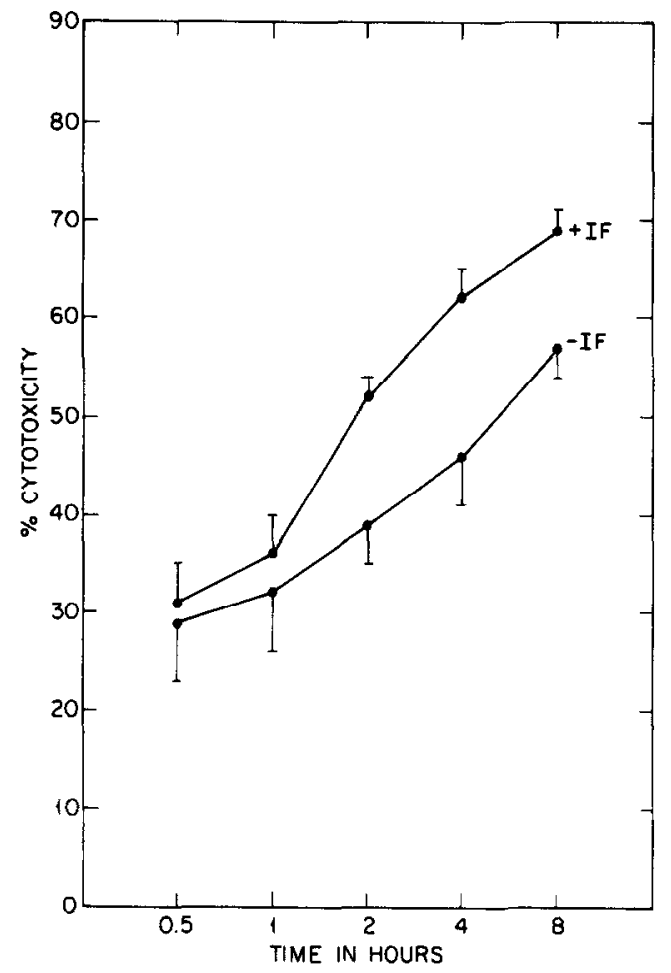

FIG. 3. Kinetics of IF augmentation of NK activity. NK cells were incubated with or without 500 $\mathrm{U} / \mathrm{ml}$ of IF for $1 \mathrm{hr}$. Percent cytotoxicity was determined at $0.5,1,2,4$, and $8 \mathrm{hr}$ after addition of labeled target cells. Results represent mean \pm SE of experiments using three different donors.

for $\mathrm{NK}$ activity and ability to incorporate $\left[{ }^{3} \mathrm{H}\right]$ thymidine. Results are presented in Fig. 4. A dose of MC $(50 \mu \mathrm{g} / \mathrm{ml})$ capable of $93-96 \%$ inhibition of $\left[{ }^{3} \mathrm{H}\right]$ thymidine incorporation (Figs. $4 \mathrm{~B}$ and $\mathrm{D}$ ) given either before (Figs. 4A and B) or after (Figs. 4C and D) IF treatment has no significant effect upon the extent of IF-induced augmentation. It appears from these findings, as well as from the temperatureindependence of IF effects upon NK activity and the expression of these effects within a brief period, that IF-induced augmentation of NK cells does not require cellular proliferation or DNA synthesis.

Effects of $A D$ on IF-induced NK augmentation. Effector cell RNA synthesis was inhibited by treatment of cells with $0.025,0.25$, or $2.5 \mu \mathrm{g} / \mathrm{ml}$ of AD for $45 \mathrm{~min}$ at $37^{\circ} \mathrm{C}$ either before or after IF treatment. Effects of $\mathrm{AD}$ on NK activity are shown in Figs. 5A and C. Effects of $A D$ on $\left[{ }^{3} \mathrm{H}\right]$ uridine incorporation are shown in Figs. 5B and D. In Fig. 5A, it can be seen that incubation of cells with AD before IF treatment not only decreases spontaneous NK activity but also inhibits the enhancement of NK activity induced by IF treatment. Results presented in Fig. 5C demonstrate that treatment with AD following $1 \mathrm{hr}$ of incubation with or without IF decreases IF-enhanced NK activity in a dose-dependent manner. However, $\mathrm{AD}$, even at high concentrations, is unable to abrogate IF-induced enhancement which remains significantly elevated when compared to spontaneous NK activity. 

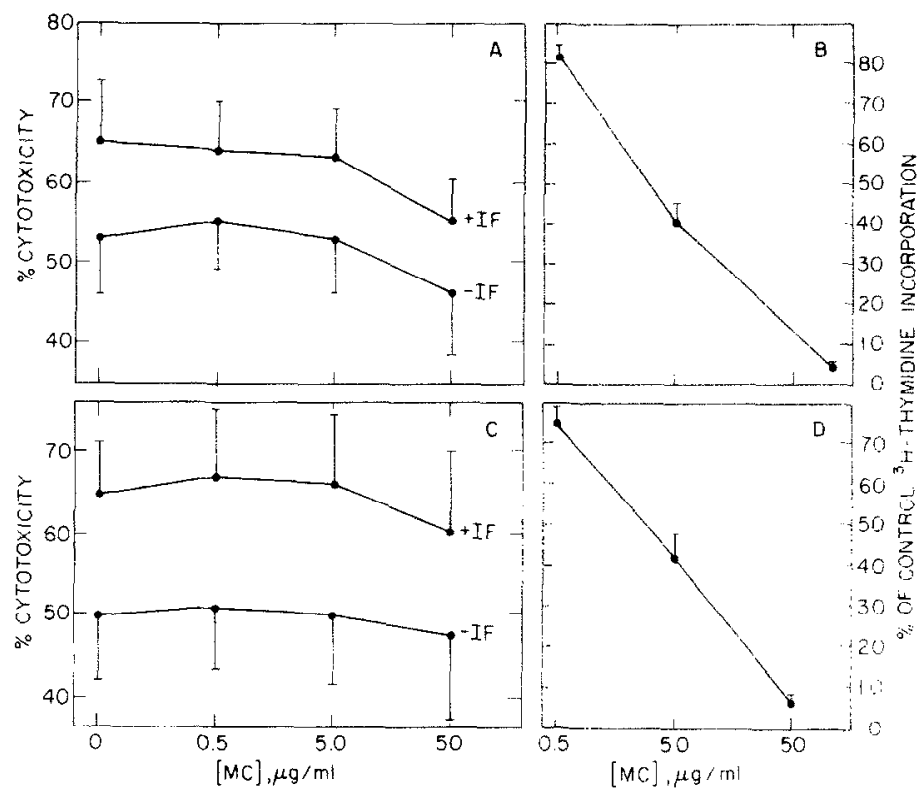

Fig. 4. Effects of mitomycin $C$ on IF augmentation of NK activity. NK cells were treated with MC either before $(A, B)$ or after (C, D) treatment with IF. B and D represent mean of results obtained with both IF-treated and untreated cells, since IF treatment did not alter uptake of $\left[{ }^{3} \mathrm{H}\right]$ thymidine. In both $\mathrm{A}$ and $C$, neither NK activity nor the extent of IF-induced augmentation of activity were significantly reduced by $\mathrm{MC}$ treatment $(P>0.05)$, Results represent mean $\pm \mathrm{SE}$ of experiments using four different donors.

The results imply that RNA synthesis is required in the initial interaction of effector cells with IF, but after $1 \mathrm{hr}$ of cell-IF contact, RNA synthesis is no longer necessary.

Effects of EM on IF-induced NK augmentation. Protein synthesis by NK effector cells was inhibited irreversibly by treatment with EM for $45 \mathrm{~min}$ at $37^{\circ} \mathrm{C}$ either prior to or following IF treatment. Results of cytoxicity assays are shown in Figs. 6A and 6C; incorporation of $\left[{ }^{3} \mathrm{H}\right]$ leucine by cells is shown in Figs. 6B and D. Treatment with EM greatly decreases spontaneous NK activity, and blocks IFinduced augmentation of activity, whether given before (Fig. 6A) or after (Fig. 6C) IF treatment.

Effects of PM on IF-induced NK augmentation. Protein synthesis in effector cells was inhibited reversibly by treatment with $0.25,2.5$, or $25 \mu \mathrm{g} / \mathrm{ml}$ of PM for 1 $\mathrm{hr}$ at $37^{\circ} \mathrm{C}$ either before or after IF treatment. Results of NK assays are presented in Figs. 7A and $\mathrm{C}$; $\left[{ }^{3} \mathrm{H}\right]$ leucine uptake is shown in Figs. 7B and D. Figure 7A demonstrates that treatment with PM before IF treatment does not significantly affect the extent of IF-mediated NK enhancement. However, the inhibitory action of PM on protein synthesis is easily reversed after the drug is washed out, as seen in Fig. 7B. Therefore, when PM was given following IF treatment (Figs. 7C and D), PM was not washed out prior to assay. In previous experiments we found that when IF and PM are added to cells simultaneously and washed out after $1 \mathrm{hr}$, the 


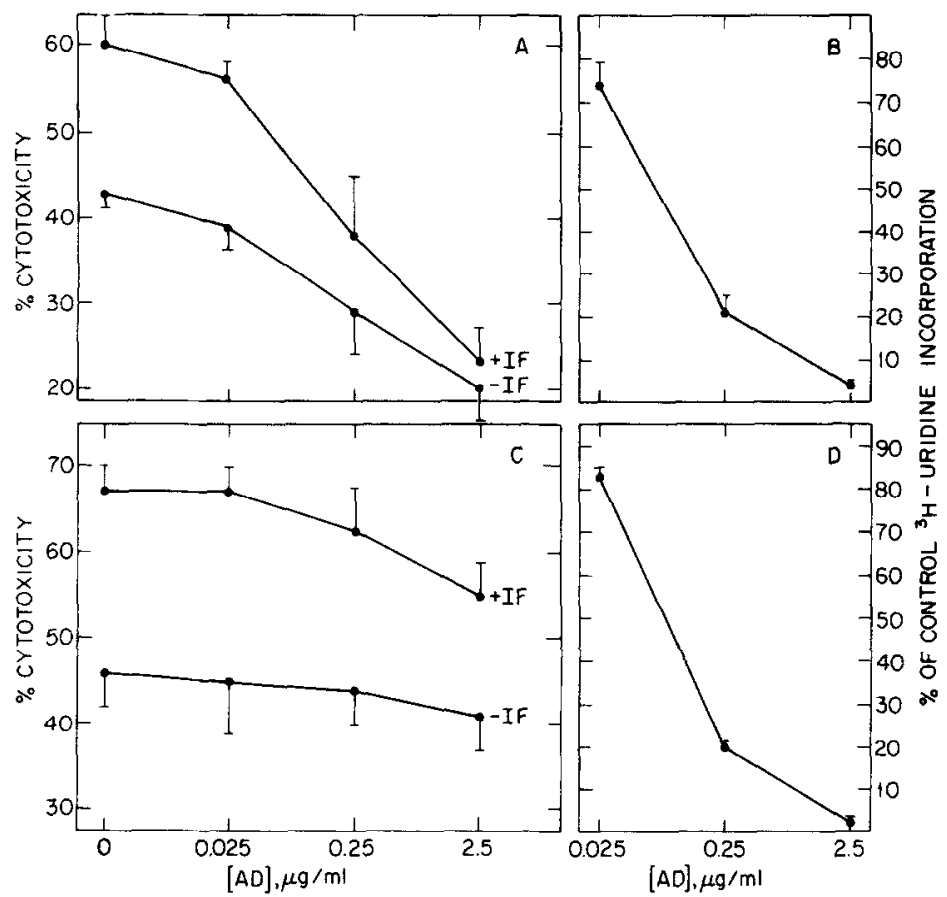

FIG. 5. Effects of actinomycin D on IF augmentation of NK activity. NK cells were treated with AD either before $(A, B)$ or after $(C, D)$ treatment with IF. B and D represent mean of results obtained with both IF-treated and untreated cells, since IF treatment did not alter uptake of $\left[{ }^{3} \mathrm{H}\right]$ uridine. (A) Both NK activity and the extend of IF-induced augmentation of activity were significantly decreased by AD treatment given prior to IF treatment $(P<0.01)$. (C) Neither NK activity nor the extent of IF-induced augmentation of activity were significantly decreased by PM treatment given following $1 \mathrm{hr}$ of IF treatment $(P>0.05)$. Results represent mean \pm SE of experiments using 4 different donors.

IF-induced augmentation of NK activity is as great as when cells are treated with IF alone. The binding of IF to NK cells thus appears to be independent of protein synthesis. If PM treatment is given after IF treatment, IF-mediated augmentation is significantly decreased, as is the ability of cells to incorporated $\left[{ }^{3} \mathrm{H}\right]$ leucine. Thus if protein synthesis is inhibited after the IF augmentation process has begun, IF-mediated enhancement of NK activity cannot proceed. Kinetic experiments are currently underway to determine at what point in the $4 \mathrm{hr} \mathrm{NK}$ assay protein synthesis can be blocked without blocking the IF augmentation process.

\section{DISCUSSION}

IF-induced augmentation of human NK activity occurs rapidly, within minutes of cell-IF interaction, and is independent of temperature. Similar independence from temperature is seen in the induction of the antiviral state by $\operatorname{IF}(26,27)$. Thus a brief interaction of cells and IF seems sufficient to initiate both induction of antiviral activity and enhancement of NK activity. Augmented NK activity following removal of IF from culture medium is evident by $30 \mathrm{~min}$ of effector cell-target contact, and is fully expressed by $2 \mathrm{hr}$. 


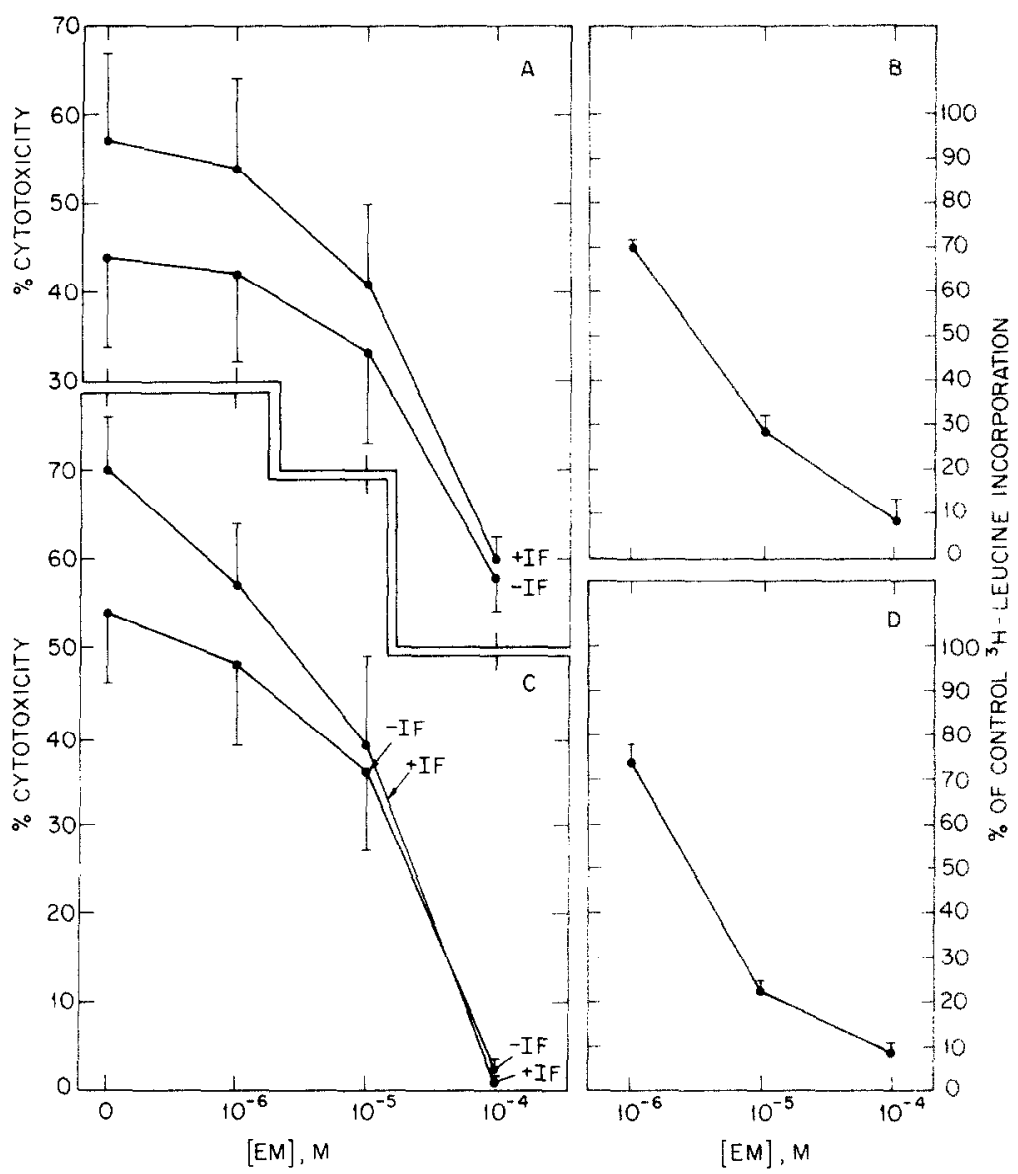

FIG. 6. Effects of emetine on IF augmentation of NK activity. NK cells were treated with EM either before (A, B) or after (C, D) treatment with IF. B and D represent mean of results obtained with both IF-treated and untreated cells, since IF treatment did not alter uptake of $\left[{ }^{3} \mathrm{H}\right]$ leucine. In both $A$ and $C$. NK activity and the extent of IF-induced augmentation of activity were significantly decreased by AD treatment $(P<0.01)$. Results represent mean \pm SE of experiments using four different donors.

New DNA synthesis is not necessary for the enhancement process, as enhancement of NK cells by IF is not blocked by MC added either before or after IF treatment. Ortaldo et al. (22), using unfractionated PBMC, also found that treatment of effector cells with MC prior to IF treatment did not reduce the resulting IF enhancement of activity. Using highly enriched NK cells, our results confirm this finding and further show that MC given after IF treatment is also ineffective in reducing enhancement of activity. Studies using a single-cell binding assay to measure NK activity have demonstrated that pretreatment of effectors with IF does not alter the number of effector-target conjugates formed, but increases the proportion of conjugates containing dead targets $(28,29)$. These results support the concept that IF does not enhance the NK reaction by causing proliferation of mature effector cells, but acts either (a) by recruiting mature NK cells from an 


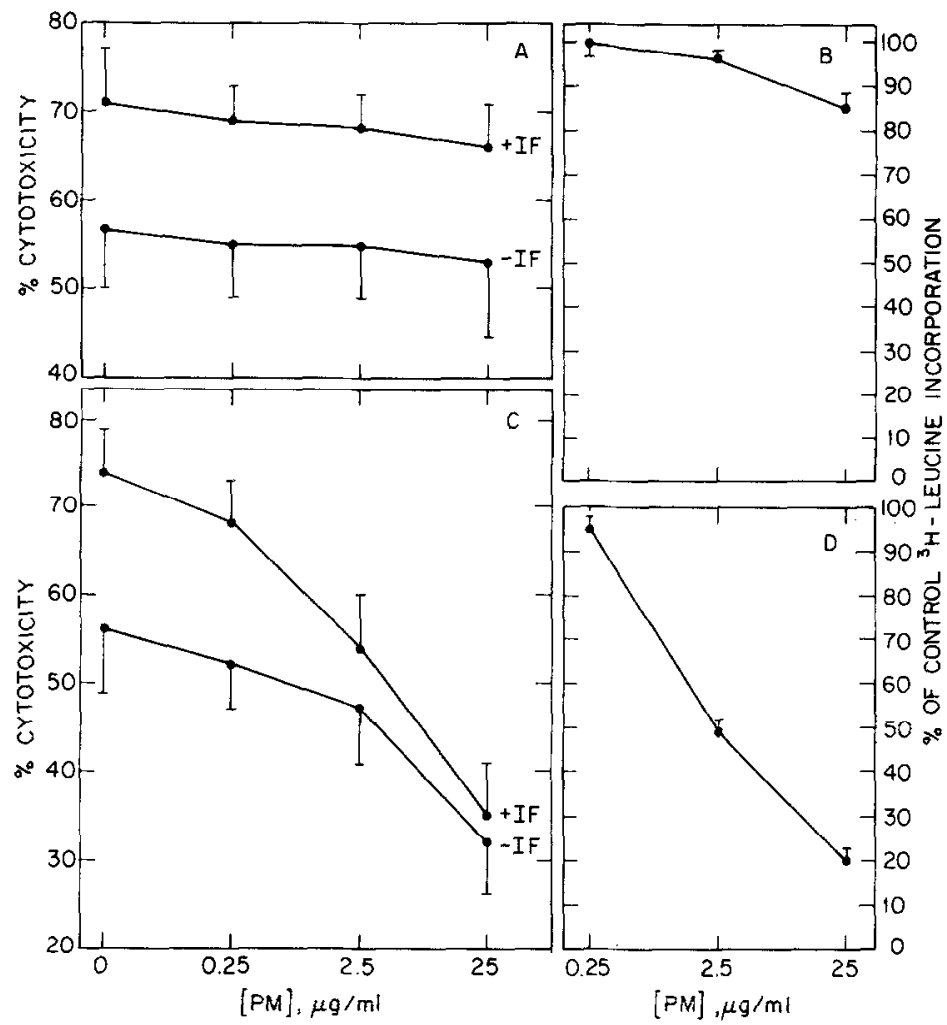

FIG. 7. Effects of puromycin on IF augmentation of NK activity. NK cells were treated with PM either before (A, B) or after (C, D) treatment with IF. B and D represent mean of results obtained with both IF-treated and untreated cells, since IF treatment did not alter uptake of $\left[{ }^{3} \mathrm{H}\right]$ leucine. (A) Neither NK activity nor the extent of IF-induced augmentation of activity were significantly decreased by PM treatment given prior to IF treatment $(P>0.05)$. (C) Both NK activity and the extent of IF-induced augmentation of activity were significantly decreased by PM treatment given following $1 \mathrm{hr}$ of IF 0.01 ). Results represent mean $\pm \mathrm{SE}$ of experiments using four different donors.

existing "pre-NK" cell population, or (b) by raising the cytotoxic efficiency of mature NK cells. Our present results are consistent with, but do not allow us to discriminate between, these two mechanisms, and it is possible that both contribute to IF-induced enhancement of NK cells.

IF-induced NK augmentation is dependent upon de novo RNA synthesis during initial cell-IF contact, since treatment of NK effector cells with AD before IF treatment results in marked inhibition of the IF-induced increase in NK activity. When cells are incubated with IF for $1 \mathrm{hr}$ prior to treatment with $\mathrm{AD}$, however, no significant decrease in the augmentation is seen, indicating that the necessary RNA is synthesized within $1 \mathrm{hr}$ of cell-IF contact. Our results parallel those of Ortaldo et al. (22); however, these investigators found that incubation of cells with IF for approximately $6 \mathrm{hr}$ was required to block subsequent inhibition of NK enhancement by AD. Since these earlier experiments used total PBMC and fibroblast or $\beta-I F$, differences in results may be attributed to differences between the 
actions of leukocyte or $\alpha$-IF and purified NK cells as used in the present studies. Alternatively, monocytes present in unfractionated PBMC, known to decrease NK activity, may antagonize the IF enhancement process, thus increasing the time required.

Effects of the protein synthesis inhibitors EM and PM clearly indicate that protein synthesis is a basic requirement of IF-induced enhancement of NK cells. Our findings in this regard are in agreement with those of Ortaldo et al. (22), who also found that pretreatment of effector cells with EM abrogates subsequent IF enhancement. By treating effector cells with EM following $1 \mathrm{hr}$ of IF treatment, we additionally demonstrate that protein synthesis is required for at least $1 \mathrm{hr}$ following removal from IF-containing medium. Binding of IF to cells, however, seems independent of protein synthesis. A requirement for protein synthesis is also a feature of IF-mediated induction of viral resistance (18), and specific enzymatic activities are known to be induced in IF-treated cells concomitant with the induction of viral resistance (30).

Although a number of similarities exist in the metabolic requirements for IFmediated enhancement of $\mathrm{NK}$ activity and induction of viral resistance, indicating that the two processes may occur via related biochemical events, it is unlikely that they possess identical mechanisms. Whereas the present study has shown that IF-mediated augmentation of NK cells is essentially complete by $60 \mathrm{~min}$, the antiviral state is not usually conferred upon cells until 6-12 hr after exposure to IF (31). Thus, it is probable that the specific RNA and protein species necessary for development of increased NK activity and viral resistance differ, as well as the cell populations affected.

A number of specific proteins could be involved in the enhancement of NK cell reactivity induced by IF. Treatment of human fibroblasts with IF induces the synthesis of at least 12 polypeptides (32), and recent evidence implies that serinedependent proteases are necessary to the NK reaction (33), along with an intact secretory apparatus (34). It is conceivable that IF could enhance NK activity by increasing the rate of synthesis or activity of proteins involved in the cytotoxic event.

Alternatively, IF could enhance NK activity in a less direct manner, perhaps by the induction of one or more lymphokines which are themselves able to stimulate NK activity. It has recently been shown that the T-cell growth factor, interleukin-2 (IL-2), increases the growth and cytotoxic activity of murine NK cells in culture (35). IF may allow NK cells to bind greater amounts of IL-2, or IF-augmented NK cells may secrete IL-2.

IF may also alter membrane receptors or target recognition sites on $\mathrm{NK}$ effector cells. IF appears to induce increased expression of the murine H-2 and human HLA antigens on cell surfaces (18), and IF may affect the expression or configuration of NK-specific structures on the effector cell membrane.

The present study has defined the metabolic requirements of the augmentation by IF of a highly enriched population of NK effector cells. It is evident, however, that much remains to be determined about the molecular mechanisms by which IF modulates the NK reaction. Our data strongly support the concept that IF acts 
upon a preexisting population of NK cells to increase their activity, rather than by causing their proliferation. This activation occurs rapidly, is temperature independent, and requires de novo RNA and protein synthesis. Proteins involved in the augmentation process may include cytotoxic proteins, lymphokines, or effector cell recognition structures. We are currently investigating these possibilities to gain increased insight into the cellular and molecular events associated with IF. mediated NK cell activation.

\section{ACKNOWLEDGMENTS}

We gratefully acknowledge the expert assistance of Dr. Ken Guire in statistical analysis of data, Dr. Thomas Carey in critical review of the manuscript, and Ms. Joan McClain in manuscript preparation. Gail A. Bishop was supported by National Institutes of Health Training Grant GM07315-07 to the Program in Cellular and Molecular Biology. These studies were supported in part by National Institutes of Health Grant AI-16216 and the Children's Leukemia Foundation of Michigan.

\section{REFERENCES}

1. Isaacs, A., and Lindenmann, J., Proc. Roy. Soc. B147, 258, 1957.

2. Einhorn, S., Blomgren, H., and Strander. H., Int. J. Cancer 22, $405,1978$.

3. Djeu, J. Y., Heinbaugh, J. A., Holden, H. T., and Herberman, R. B., J. Immunol. 122, $175,1979$.

4. Droller, M. J., Borg, H., and Perlmann, P., Cell. Immunol. 47, 248, 1979.

5. Herberman, R. B., Ortaldo, J. R., and Bonnard, G. D., Nature (London) 277, 221, 1979a.

6. Ullberg, M., and Jondal, M., J. Exp. Med. 153, 615, 1981.

7. Saksela, E., Timonen, T., Ranki, A., and Hayry, P., Immunol. Rev. 44, 71, 1979.

8. Timonen, T., and Saksela, E., J. Immunol. Methods 36, 285, 1980.

9. O'Toole. C., Stejskal, V., Perlmann, P., and Karlson, M., J. Exp. Med. 139, 457, 1974.

10. Haller, O., Hansson, M., Kiessling, R., and Wigzell, H., Nature (London) 270, 609, 1977.

11. Nair, P. N. M., Fernandes, G., Onoe, K., Day. N. K., and Good, R. A., Int. J. Cancer 25, 667, 1980.

12. Flannery, G. R., Robins, R. A., and Baldwin, R. W., Cell. Immunol. 61, 1, 1981.

13. Moore, M., and Vose, B. M., Int. J. Cancer 27, 265, 1981.

14. Ziegler, H. W., Kay, N. E., and Zarling, J. M., Int. J. Cancer 27, 321, 1981.

15. Cudkowicz, G., and Hochman, P. S., Immunol. Rev. 44, 13, 1979.

16. Nair, P. N. M., and Schwartz, S. A., J. Immunol. 126, 2221, 1981.

17. Riccardi, C., Santoni, A., Barlozzari, T., and Herberman, R. B., Cell. Immunol. 60, 136, 1981.

18. Stewart II, W. E., “The Interferon System" (2nd ed.), Springer-Verlag, New York, 1981.

19. Herberman, R. B., Djeu, J. Y., Kay, H. D., Ortaldo, J. R., Riccardi, C., Bonnard, G. D., Holden, H. T., Fagnani, R., Santoni, A., and Puccetti, P., Immunol. Rev. 44, 43, 1979 b.

20. Senik, A., Kolb, J. P., Orn, A., and Gidlund, M., Scand. J. Immunol. 12, 51, 1980.

21. Djeu, J. Y., Stocks, N., Varesio, L., Holden, H. T., and Herberman, R. B., Cell. Immunol. 58, 49, 1981.

22. Ortaldo, J. R., Phillips, W., Wasserman, K., and Herberman, R. B., J. Immunol. 125, 1839, 1980.

23. Böyum, A., Scand. J. Clin. Lab. Invest. 21, (Suppl. 97), 77, 1968.

24. Ly, I., and Mishell, R., J. Immunol. Methods 5, 239, 1974.

25. Andersson, L., Nilsson, K., and Gohmberg, C., Int. J. Cancer 23, 143, 1979.

26. Auget, M., Nature (London) 284, 459, 1980.

27. Friedman, R. M., In "Interferon 1" (I. Gresser, Ed.), pp. 53-72, Academic Press, New York. 1979.

28. Silva, A., Bonavida, B., and Targan, S., J. Immunol. 125, 479, 1980.

29. Targan, S., and Dorey, F., J. Immunol. 124, 2157, 1980.

30. Baglioni, C., Cell 17, 255, 1979.

31. Revel, M., In "Interferon 1"' (I. Gresser, Ed.), pp. 102-157, Academic Press, New York, 1979.

32. Weil, J., Epstein, L. B., and Epstein, C. J., J. Interferon Res. 1, 111, 1980.

33. Hudig, D., Haverty, T., Fulcher, C., Redelman, D., and Mendelsohn, J., J. Immunol. 126, 1569, 1981 .

34. Carpen, O., Virtanen, I., and Saksela, E., Cell. Immunol. 58, 97, 1981.

35. Kuribayashi, K., Gillis, S., Kern, D. E., and Henney. C. S., J. Immunol. 126, 2321, 1981.

Received March 29, 1982; accepted with revisions July 1, 1982. 